\title{
PENGARUH BIAYA PROMOSI TERHADAP TINGKAT PENJUALAN PADA DEALER PUTRA RAMA JAYA HONDA KOTA PONOROGO
}

\author{
Emi Susilawati \\ Mahasiswa Prodi Pendidikan Ekonomi IKIP PGRI MADIUN
}

\begin{abstract}
Abstrak: Penelitian ini bertujuan : 1) untuk mengetahui biaya promosi di Putra Rama Jaya Honda Dealer Ponorogo di 2011-2012. 2) untuk mengetahui tingkat penjualan di Putra Rama Jaya Honda Dealer Ponorogo di 2011-2012. 3) untuk mengetahui pengaruh antara biaya promosi terhadap kelas dijual di Honda Putra Rama Jaya Dealer Ponorogo di 2011-2012. Sampel pada penelitian ini, yaitu mengambil berdasarkan semua anggota populasi sebagai sampel. Untuk mengambil adalah biaya promosi dan nilai penjualan selama 24 bulan, yaitu pada 2011-2012, pengumpulan laporan menggunakan metode dokumentasi. Untuk analisis laporan ini menggunakan tes sederhana dari regresi linier, tes korelation dan uji t. Hasil pemeriksaan menunjukkan bahwa biaya promosi tidak ada pengaruh sekaligus koneksi positif terhadap tingkat penjualan di Putra Rama Jaya Honda Dealer Ponorogo. Intinya didapatkan dari nilai $r_{\text {tabel }}=24-2=22$ adalah 0.404; Namun jenis tes adalah jika $r_{\text {hitung }}>r_{\text {tabel }}$ maka Ha adalah diterima dan Ho adalah ditolak dan jika saya menghitung $<$ I tabel atau, 0244 $<0404$ itu berarti Ha ditolak dan Ho adalah diterima, yang tidak memiliki hubungan yang signifikan antara biaya promosi dan tingkat penjualan di Agen Honda Putra Rama Jaya Ponorogo $\mathrm{T}_{\text {tabel }}=24-2=22$ adalah 4.300; Namun jenis terbaik adalah jika $\mathrm{F}_{\text {hitung }}>\mathrm{F}_{\text {tabel }}$ maka Ha ditolak dan Ho adalah diterima. Berdasarkan jenis tes menjelaskan yang $\mathrm{F}_{\text {hitung }}<\mathrm{F}_{\text {tabel }}$ atau, $1.394<4.300$ itu berarti Ha adalah ditolak dan Ho adalah diterima, yang tidak pengaruh signifikan antara biaya promosi dan nilai penjualan di Agen Putra Rama Jaya Honda Ponorogo. $T_{\text {tabel }}=24-2=22$ adalah 1.717; Namun jenis tes jika $t_{\text {hitung }}>t_{\text {tabel }}$ maka Ha diterima dan Ho ditolak dan jika $t_{\text {hitung }}>t_{\text {tabel }}$ maka Ha ditolak dan Ho adalah diterima. Berdasarkan jenis tes menjelaskan bahwa $t_{\text {hitung }}>t_{\text {tabel }}$ atau $1.223<1.717$ itu berarti Ha ditolak dan Ho adalah diterima, yang tidak pengaruh yang signifikan antara biaya promosi dan nilai penjualan di Dealer Honda Putra Rama Jaya Ponorogo dan pengaruh oleh faktor lain.
\end{abstract}

Kata Kunci : Biaya Promosi, Tingkat Penjualan

\section{PENDAHULUAN}

Salah satu faktor terpenting dalam menunjang keberhasilan suatu perusahaan adalah strategi pemasaran. Bagaimana sempurnanya perencanaan maupun peralatan yang dimiliki suatu perusahaan tanpa adanya sasaran pemasaran yang jelas maka tidaklah mungkin perusahaan tersebut dapat berjalan sebagaimana mestinya. Untuk memajukan pemasaran perusahaan tersebut dapat melakukan kegiatan promosi.

Kegiatan promosi tidak hanya berupa pertukaran barang, tetapi juga mencakup distribusi sejumlah jasa yang dapat memberikan kebutuhan dan kepuasan kepada individu dan organisasi. Sehingga segala usaha perusahaan dapat terus berjalan dan mendapat pandangan yang baik dari konsumen terhadap perusahaan. Usaha ini dapat dilakukan dengan melalui dealer. Dealer merupakan perusahaan yang mempunyai kedudukan khusus dalam menjual barang dagangan bermerek tertentu dan menjualnya kepada konsumen.

Kegiatan promosi sebagai salah satu alat penunjang tingkat penjualan, perusahaan juga harus dapat menginformasikan dengan cermat pada benak pelanggan. Untuk itu perusahaan harus mampu menggunakan alat promosi seperti advertising, personal selling, 
sales promotion, dan publicity.

Masing-masing dealer saling bersaing untuk menarik hati konsumen. Akibatnya dealer yang tidak bisa menguasai metodemetode pemasaran untuk produk yang dijual, misalnya biaya promosi sampai biaya insentif karyawan maka dealer ini akan mengalami penurunan penjualannya, biar pun produk tersebut kualitasnya tinggi. Seperti yang terjadi pada dealer Putra Rama Jaya Honda di Kabupaten Ponorogo ini yang terletak di Jalan Gajah Mada 29 Ponorogo.

Menurut Freddy Rangkuti (2009:55) menyatakan bahwa "Biaya merupakan faktor yang sangat penting dalam melaksanakan berbagai kegiatan, apa pun jenis kegiatan itu. Terlebih lagi bagi kegiatan di bidang pemasaran, khususnya promosi. Setiap kegiatan promosi yang dilakukan oleh perusahaan tentunya memerlukan biaya. Besarnya biaya yang dikeluarkan oleh perusahaan tergantung pada alat promosi yang digunakan”.

Menurut Saladin dalam Freddy Rangkuti (2003:49) menyatakan bahwa "Promosi adalah penyampaian informasi dari penjualan kepada pembeli yang berperan dalam memperkenalkan, memberitahukan dan meningkatkan kembali manfaat suatu produk yang dipromosikan tersebut". Promosi dibutuhkan untuk membantu perusahaan dalam mengadakan komunikasi dengan konsumen, karena dengan promosi dapat disampaikan informasi mengenai produk atau jasa tentang kelebihan atau kebaikannya jika dibandingkan dengan produk atau jasa lain.

Menurut Kotler dan Amstrong dalam Freddy Rangkuti (2003:55) menyatakan bahwa "Jika analisis suatu perusahaan menunjukkan beban utama harus diletakkan pada periklanan, maka biaya promosi yang dikeluarkan oleh perusahaan lebih kecil, jika dibandingkan dengan promosi yang menggunakan penjualan pribadi”.

"Biaya promosi adalah pengorbanan ekonomis yang menjadi beban perusahaan untuk melaksanakan kegiatan promosinya. Dari penjelasan di atas dapat dilihat bahwa biaya merupakan suatu pengorbanan ekonomis yang dikeluarkan oleh perusahaan yang menghasilkan barang dan jasa, dimana biaya tersebut dinyatakan dalam bentuk uang" (Freddy Rangkuti, 2009: 56).

Sedangkan menurut Kotler dalam Freddy Rangkuti (2006:205) menyatakan bahwa "Biaya promosi merupakan faktor kunci karena keputusan utama ini akan sangat berpengaruh terhadap efektivitas program kegiatan promosi dan efektivitas perolehan laba perusahaan dilakukan". Setiap keputusan yang dapat dipertanggungjawabkan adalah keputusan yang mempertimbangkan antara hasil yang didapat dengan biaya yang dikeluarkan untuk memperoleh hasil tersebut.

Menurut Freddy Rangkuti (2009:55) menyatakan bahwa "Biaya merupakan faktor yang sangat penting dalam melaksanakan berbagai kegiatan, apapun jenis kegiatan itu. Terlebih lagi bagi kegiatan di bidang pemasaran, khususnya promosi. Setiap kegiatan promosi yang dilakukan oleh perusahaan tentunya memerlukan biaya. Besarnya biaya yang dikeluarkan oleh perusahaan tergantung pada alat promosi yang digunakan".

Menurut Basu Swasta (2008:349) "Promosi adalah arus informasi atau persuasi satu arah yang dibuat untuk mengarahkan seseorang atau organisasi kepada tindakan yang menciptakan pertukaran dalam pemasaran".

Adapun menurut Bilso Simamora (2001:285) "Promosi adalah suatu proses komunikasi, mempelajari promosi berarti mempelajari juga komunikasi”.

Sedangkan Promosi menurut Eddy Soeyanto (2009:204) "Promosi merupakan bentuk pengenalan perusahaan atau produk kepada publik, di samping untuk memperkenalkan promosi bertujuan untuk menarik pelanggan baru atau meningkatkan penjualan".

Selain itu Indriyo Gitosudarmo (2001: 214) berpendapat bahwa "Promosi merupakan kegiatan yang ditujukan untuk mempengaruhi konsumen agar mereka dapat men- 
jadi kenal akan produk yang ditawarkan oleh perusahaan kepada mereka dan kemudian mereka senang lalu membeli produk tersebut.

\section{DEFINISI PROMOSI}

Menurut Preddy Rangkuti (2009:177) menyatakan bahwa "Bauran promosi merupakan pemasaran mengembangkan promosi untuk mengkomunikasikan informasi mengenai produk mereka dan mempengaruhi konsumen untuk membelinya. Untuk menciptakan dan memelihara keunggulan pembeda dari apa yang ditawarkan pesaing maka sebagian besar produk dan merk yang berhasil membutuhkan promosi".

Keempat jenis promosi Peter dan Olson dalam Freddy Rangkuti (2009:178) adalah:

1). Iklan

Iklan (advertising) adalah penyajian informasi nonpersonal mengenai produk, merek, perusahaan atau toko yang dilakukan dengan bayaran tertentu. Pada iklan biasanya ditampakkan organisasi yang mensponsorinya. Iklan ditujukan untuk mempengaruhi afeksi dan kognisi konsumen. Dalam praktiknya, iklan telah dianggap sebagai manajemen citra (image management), menciptakan dan memelihara citra dan makna dalam benak konsumen. Iklan dapat disajikan melalui berbagai macam media (TV, radio, cetakan majalah, surat kabar, papan billboard, papan tanda, dan macammacam media). "Iklan merupakan salah satu bentuk dari komunikasi impersonal (impersonal communication) yang digunakan oleh perusahaan baik barang/ jasa. Peranan periklanan dalam pemasaran jasa adalah untuk membangun kesadaran" (Rambat Lupiyoadi, 2001: 108).

2). Promosi Penjualan

Promosi penjualan (sales promotion) adalah rangsangan langsung yang ditunjukkan kepada konsumen untuk melakukan pembelian. Banyaknya jenis promosi penjualan termasuk di dalamnya penu- runan harga temporer melalui kupon, rabat, penjualan multi kardus, kontes dan undian, perangko dagang, pameran dagang, dan eksibisi.

Sedangkan tujuan dari promosi penjualan menurut Basu Swastha (2007:280) adalah: (1). Tujuan Promosi Penjualan Intern, (2). Tujuan Promosi Penjualan Perantara, (3). Tujuan Promosi Penjualan Konsumen.

3). Penjualan Personal

Penjualan personal (personal selling) melibatkan interaksi personal langsung antara seorang pembeli potensial dan seorang salesmen. Penjualan personal dapat menjadi metode promosi yang hebat untuk 2 alasan berikut. Pertama, komunikasi personal dengan salesmen dapat meningkatkan keterlibatan konsumen dengan produk dan atau proses pengambilan keputusan.

4). Publisitas

Publisitas (publicity) adalah bentukbentuk komunikasi tentang perusahaan, produk, atau merk si pemasar yang tidak membutuhkan pembayaran. Misalnya, penjabaran produk atau merek baru, perbandingan merek di jurnal dagang, surat kabar, majalah berita, diskusi di radio dan talk show di TV semuanya menyajikan berbagai informasi produk bagi para konsumen.

\section{TUJUAN PROMOSI}

"Setiap perusahaan yang melakukan sesuatu kegiatan tentu mempunyai tujuan. Demikan juga, perusahaan melakukan kegiatan promosi dengan tujuan utamanya untuk mencari laba" (Freddy Rangkuti, 2009: 51). Pada umumnya kegiatan promosi yang dilakukan oleh perusahaan harus mendasarkan kepada tujuan sebagai berikut :

1). Modifikasi tingkah laku

Pasar merupakan tempat pertemuan orang-orang yang hendak melakukan suatu pertukaran di mana orang-orangnya terdiri atas berbagai macam tingkah laku 
yang satu sama lain saling berbeda. Demikian juga pendapat mereka mengenai suatu barang dan jasa, selera, motivasi, dan kesetiaannya terhadap barang dan jasa tersebut saling berbeda.

2). Memberitahu

Kegiatan promosi yang ditujukan untuk memberikan informasi kepada pasar yang dituju tentang pemasaran perusahaan, mengenai produk tersebut berkaitan dengan harga, kualitas, syarat pembeli, kegunaan, keistimewaan, dan lain sebagainya. Promosi yang bersifat informasi ini umumnya lebih disukai dan dilakukan pada tahap-tahap awal dalam siklus kehidupan produk.

3). Membujuk

Promosi yang bersifat membujuk atau miring ini pada umumnya kurang disenangi oleh sebagian masyarakat. Tetapi kenyataannya, sekarang ini yang banyak muncul justru adalah promosi tersebut. Promosi seperti itu terutama untuk mendorong pembeli. Perusahaan tidak ingin memperoleh tanggapan secepatnya, tetapi lebih mengutamakan untuk menciptakan kesan positif.

4). Mengingatkan

Promosi yang bersifat mengingatkan ini dilakukan terutama untuk mempertahankan merk produk di hati masyarakat dan dilakukan selama tahap kedewasaan dalam siklus kehidupan produk. Ini berarti perusahaan berusaha memperhatikan untuk mempertahankan pembeli yang ada sebab pembeli tidak hanya sekali saja melakukan transaksi, melainkan harus berlangsung secara terus-menerus.

Tidak ada artinya jika perusahaan memproduksi suatu barang atau jasa tidak diketahui oleh konsumen. Agar produknya dikenal oleh konsumen, maka jalan yang ditempuh perusahaan adalah melalui kegiatan promosi. Suatu promosi yang digunakan dengan tema yang menarik akan lebih cepat mendapatkan perhatian dari konsumen, sehingga menyebabkan konsumen mempunyai kehendak untuk membeli barang yang dipromosikan oleh perusahaan.

Kegiatan penjualan merupakan kegiatan pelengkap atau suplemen dari pembelian, untuk memungkinkan terjadinya transaksi. Jadi kegiatan pembelian dan penjualan merupakan satu kesatuan untuk dapat terlaksananya transfer hak atau transaksi. Oleh karena itu, kegiatan penjualan seperti halnya kegiatan pembelian, terdiri dari serangkaian kegiatan yang meliputi penciptaan permintaan (demand), menemukan si pembeli, negosiasi harga, dan syarat-syarat pembayaran.

"Penjualan adalah pemindahan hak milik atas barang atau pemberian jasa yang dilakukan penjualan kepada pembelian dengan harga yang disepakati bersama dengan jumlah yang dibebankan kepada pelanggan dalam penjualan barang/jasa dalam suatu periode" (Freddy Rangkuti, 2009:57).

"Penjualan merupakan tujuan utama dilakukannya kegiatan perusahaan. Perusahaan dalam menghasilkan barang/jasa mempunyai tujuan akhir, yaitu untuk menjual barang/jasa tersebut kepada masyarakat. Oleh karena itu, penjualan memegang peranan penting bagi perusahaan agar produk yang dihasilkan oleh perusahaan dapat terjual dan memberikan penghasilan bagi perusahaan" (Freddy Rangkuti, 2009:57).

Menurut Sofjan Assauri (2010:23) menyatakan bahwa "Kegiatan penjualan merupakan kegiatan pelengkap atau suplemen dari pembelian, untuk memungkinkan terjadinya transaksi."

\section{FAKTOR-FAKTOR YANG MEM- PENGARUHI PENJUALAN}

Menurut Basu Swastha (2008:406) menyatakan bahwa "Kegiatan penjualan itu dipengaruhi oleh beberapa faktor”. Faktorfaktor tersebut adalah :

1). Kondisi dan Kemampuan Penjualan Transaksi jual-beli atau pemindahan hak 
milik secara komersial atas barang atau jasa itu pada prinsipnya melibatkan dua pihak, yaitu penjual sebagai pihak pertama dan pembeli sebagai pihak kedua. Di sini, penjual harus dapat meyakinkan kepada pembelinya agar dapat berhasil mencapai sasaran penjualan yang diharapkan.

Untuk maksud tersebut penjual harus memahami beberapa masalah penting yang sangat berkaitan yakni :

a) Jenis dan karakteristik barang yang ditawarkan.

b) Harga produk.

c) Syarat penjualan, seperti : pembayaran, penghantaran, pelayanan sesudah penjualan, garansi, dan sebagainya.

Masalah-masalah tersebut biasanya menjadi pusat perhatian pembeli sebelum melakukan pembelian. Selain itu, manajer perlu memperhatikan jumlah serta sifatsifat tenaga penjualan yang akan dipakai. Dengan tenaga penjualan yang baik dapat lah dihindari timbulnya kemungkinan rasa kecewa pada para pembeli dalam pembeliannya.

Adapun sifat-sifat yang perlu dimiliki oleh seorang penjual yang baik antara lain : sopan, pandai bergaul, pandai berbicara, mempunyai kepribadian yang menarik, sehat jasmani, jujur, mengetahui cara-cara penjualan dan sebagainya.

2). Kondisi Pasar

Pasar, sebagai kelompok pembeli atau pihak yang menjadi sasaran dalam penjualan, dapat pula mempengaruhi kegiatan penjualannya. Adapun faktorfaktor kondisi pasar yang perlu diperhatikan adalah :

a) Jenis pasarnya, apakah pasar konsumen, pasar industri, pasar penjual, pasar pemerintah, ataukah pasar internasional.

b) Kelompok pembeli atau segmen pasarnya. c) Daya belinya.

d) Frekuensi pembeliannya.

e) Keinginan dan kebutuhannya.

3). Modal

Akan lebih sulit bagi penjual untuk menjual barangnya apabila barang yang dijual tersebut belum dikenal oleh calon pembeli, atau apabila lokasi pembeli jauh dari tempat penjual. Dalam keadaan seperti ini, penjual harus memperkenalkan dulu membawa barangnya ke tempat pembeli. Untuk melaksanakan maksud tersebut diperlukan adanya sarana serta usaha, seperti : alat transport, tempat peragaan baik di dalam perusahaan maupun di luar perusahaan, usaha promosi, dan sebagainya.

4). Kondisi Organisasi Perusahaan

Pada perusahaan besar, biasanya masalah penjualan ini ditangani oleh bagian tersendiri (bagian penjualan) yang dipegang orang-orang tertentu/ahli di bidang penjualan. Lain halnya dengan perusahaan kecil di mana masalah penjualan ditangani oleh orang yang juga melakukan fungsifungsilain.

Hal ini disebabkan karena jumlah tenaga kerjanya lebih sedikit, sistem organisasinya lebih sederhana, masalah-masalah yang dihadapi, serta sarana yang dimilikinya juga tidak sekompleks perusahaan besar. Biasanya masalah penjualan ini ditangani sendiri oleh pimpinan dan tidak diberikan.

5). Faktor lain

Faktor-faktor lain, seperti : periklanan, peragaan, kampanye, pemberian hadiah, sering mempengaruhi penjualan.

Upaya memperkenalkan produk kepada konsumen merupakan awal dari kegiatan promosi. Promosi tidak hanya sebatas memperkenalkan produk kepada konsumen saja, akan tetapi harus dilanjutkan dengan upaya untuk mempengaruhi konsumen tersebut agar menjadi senang kemudian membeli produknya. 
Sedangkan tingkat penjualan merupakan keadaan di mana perusahaan mampu menjual suatu produk kepada konsumen dalam jumlah tertentu. Tingkat penjualan yang menguntungkan merupakan tujuan dari pemasaran, maksudnya tingkat penjualan/ laba yang diperoleh dari pemuasan kebutuhan konsumen. Untuk dapat mencapai tingkat penjualan yang menguntungkan perusahaan perlu menitikberatkan kegiatan pemasaran pada variabel marketing mix yaitu keputusan dan strategi mengenai produk, harga, promosi dan saluran distribusi.

Dengan menggunakan salah satu variabel promosi konsumen akan tertarik dan menimbulkan minat beli, dengan demikian target pasar dapat tercapai. Tercapainya target pasar maka tingkat penjualan diharapkan dapat menguntungkan semua kegiatan pemasaran pada umumnya ditujukan untuk meningkatkan tingkat penjualan. Dengan demikian promosi erat kaitannya dengan tingkat penjualan terutama dalam upaya mempengaruhi konsumen akan produk yang ditawarkan pada Dealer Putra Rama Jaya Honda di Kota Ponorogo.

Hal ini dipertegas oleh Eddy Soeyanto (2009:204) "Promosi merupakan bentuk pengenalan perusahaan atau produk kepada publik, di samping untuk memperkenalkan promosi bertujuan untuk menarik pelanggan baru atau meningkatkan penjualan".

\section{METODE PENELITIAN}

Metode yang digunakan dalam penelitian ini adalah metode penelitian kuantitatif. Sugiyono (2007:8) menyatakan "Metode penelitian kuantitatif dapat diartikan sebagai metode penelitian yang berlandaskan pada filsafat positivisme, digunakan untuk meneliti pada populasi atau sampel tertentu, pengumpulan data yang menggunakan instrumen penelitian, analisis data bersifat kuantitatif/statistik, dengan tujuan untuk menguji hipotesis yang telah ditetapkan".

Sedangkan Algifari (2003:9) mengatakan "Data kuantitatif adalah nilai data yang yang dinyatakan dalam skala numerik (angka) yang diolah dengan metode statistik.

Variabel yang digunakan dalam penelitian ini yaitu variabel bebas dan variabel terikat".

Desain penelitian adalah sebagai berikut :

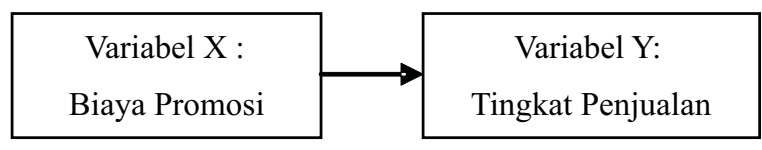

\section{VARIABEL PENELITIAN}

1. Variabel bebas

Menurut Burhan Bungin (2009:62) berpendapat bahwa "Variabel bebas adalah variabel yang menentukan arah atau perubahan tertentu pada variabel tergantung, sementara variabel bebas berada pada posisi yang lepas dari "pengaruh variabel tergantung". Dalam penelitian ini variabel bebasnya adalah biaya promosi pada Dealer Putra Rama Jaya Honda Kota Ponorogo.

2. Variabel terikat

"Variabel tergantung adalah variabel yang 'dipengaruhi' oleh variabel bebas" (Burhan Bungin, 2009:62). Dalam penelitian ini variabel terikatnya adalah tingkat penjualan pada Dealer Putra Rama Jaya Honda Kota Ponorogo.

\section{TEKNIK PENGUMPULAN DATA}

Teknik pengumpulan data dalam penelitian ini dimaksudkan untuk memperoleh bahan-bahan, keterangan atau informasi yang dipercaya. Pengumpulan teknik dan alat pengumpulan yang tepat memungkinkan data yang obyektif. Teknik pengumpulan data yang digunakan dalam penelitian ini dengan menggunakan teknik pengumpulan data dengan metode dokumentasi dan wawancara.

1. Dokumentasi merupakan cara pengumpulan data dengan mengambil peninggalan tertulis, seperti arsip-arsip dan termasuk juga buku-buku tentang pendapat teori, dan lain-lainnya yang berhubungan dengan masalah penelitian. Menurut 
Burhan Bungin (2005:144) berpendapat bahwa "Metode dokumentasi adalah salah satu metode pengumpulan data yang digunakan dalam metodologi penelitian sosial". Sedangkan Gabriel Amin (2003: 82) berpendapat bahwa "Metode dokumentasi ini pada umumnya didapat dari data-data perusahaan".

2. Wawancara Menurut Burhan Bungin (2005:132) "Wawancara adalah memperhatikan kemampuan pewawancara dalam mengendalikan wawancaranya.

Dokumentasi dan wawancara yang diperlukan oleh peneliti berupa data pada Dealer Putra Rama Jaya Honda pada bulan Januari 2011 sampai bulan Desember 2012 terdapat data biaya promosi dan tingkat penjualan. Untuk mendapatkan data ini, peneliti harus menemui kepala promosi Dealer Putra Rama Jaya Honda dengan membawa surat permohonan penelitian dari lembaga kemudian menanyakan tentang biaya promosi dan tingkat penjualannya.

\section{POPULASI DAN SAMPEL PENE- LITIAN}

"Populasi penelitian merupakan keseluruhan (universum) dari objek penelitian yang dapat berupa manusia, hewan, tumbuh-tumbuhan, udara, gejala, nilai, peristiwa, sikap, hidup, dan sebagainya, sehingga objek-objek ini dapat menjadi sumber data penelitian" (Burhan Bungin, 2009:99).

Sedangkan menurut Andi Supangat (2007:3) yang menyatakan bahwa "Populasi, yaitu sekumpulan objek yang dijadikan sebagai bahan penelitian (penelahan) dengan ciri mempunyai karakteristik yang sama".

Populasi dalam penelitian ini adalah dari 2011 sampai 2012 selama 24 bulan pada Dealer Putra Rama Jaya Honda Kota Ponorogo.

"Sampling adalah cara pengumpulan data apabila yang diselidiki adalah elemen sampel dari suatu populasi" (Supranto, 2008: 23).
Sedangkan menurut Andi Supangat (2007:4) berpendapat bahwa "Sampel yaitu bagian dari populasi (contoh), untuk dijadikan sebagai bahan penelaahan dengan harapan contoh yang diambil dari populasi tersebut dapat mewakili (representative) terhadap populasinya". Penelitian ini merupakan penelitian populasi karena semua populasi dijadikan subjek sampel.

\section{HASIL PENELITIAN VARIABEL BIAYA PROMOSI}

Deskripsi dari variabel biaya promosi dengan jumlah $\mathrm{N}$ (24) diperoleh hasil: a) Nilai jumlah total skor sebesar 261,000; b) Nilai mean 10,875,00; c) Nilai median 11,000,00; d) Nilai mode 10,000; e) Nilai standar deviasi 1101,481 ; f) Nilai minimum 9,000; g) Nilai maximum 12,600. Dari hasil analisa statistik deskriptif di atas biaya promosi di Dealer Putra Rama Jaya Honda adalah baik, karena jumlah data yang berada di atas nilai rata-rata sebanyak 13 bulan atau $54,17 \%$ dan di atas $50 \%$.

\section{VARIABEL TINGKAT PENJUALAN}

Deskripsi dari variabel tingkat penjualan dengan jumlah N (24): a) Nilai jumlah total skor sebesar 6071,00; b) Nilai mean 252,958,3; c) Nilai median 237,000,0; d) Nilai mode 288,00 ; e) Nilai standar deviasi 51,434,62; f) Nilai minimum 184,00; g) Nilai maximum 357,00. Dari hasil analisa statistik deskriptif di atas tingkat penjualan di Dealer Putra Rama Jaya Honda adalah kurang baik, karena jumlah data yang berada di bawah nilai rata-rata sebanyak 11 bulan atau 46,83\%.

\section{HASIL UJI KORELASI}

Berdasarkan hasil perhitungan korelasi $\mathrm{r}$ dapat diketahui besarnya korelasi (r) adalah 0,244 yang merupakan korelasi positif yaitu jika jumlah biaya promosi (X) meningkat maka secara proposional jumlah tingkat penjualan (Y) juga meningkat. Demikian sebaliknya, apabila jumlah biaya promosi (X) juga akan menurun secara proposional tingkat penjualan (Y) juga akan menurun. 
HASIL UJI FISHER

\begin{tabular}{|c|c|c|c|c|c|c|}
\hline \multicolumn{7}{|c|}{ ANOVA $^{b}$} \\
\hline & Model & $\begin{array}{l}\text { Sum of } \\
\text { Squares }\end{array}$ & df & $\begin{array}{c}\text { Mean } \\
\text { Square }\end{array}$ & $\mathrm{F}$ & Sig. \\
\hline & Regression & 3625.576 & 1 & 3625.576 & 1.394 & $.250^{\mathrm{a}}$ \\
\hline & Residual & 57221.382 & 22 & 2600.972 & & \\
\hline & Total & 60846.958 & 23 & & & \\
\hline
\end{tabular}

Berdasarkan hasil perhitungan di atas dapat diketahui besarnya uji fisher adalah 1,394 yaitu jika jumlah biaya promosi (X) meningkat maka secara proposional jumlah tingkat penjualan (Y) juga meningkat. Demikian sebaliknya, apabila jumlah biaya promosi (X) juga akan menurun secara proposional tingkat penjualan (Y) juga akan menurun.

\section{HASIL UJI t}

Berdasarkan hasil perhitungan uji $\mathrm{t}$ dapat diketahui besarnya uji $\mathrm{t}$ adalah 1,181 jika jumlah biaya promosi (X) meningkat maka secara proposional jumlah tingkat penjualan (Y) juga meningkat. Demikian sebaliknya, apabila jumlah biaya promosi (X) juga akan menurun secara proposional tingkat penjualan(Y) juga akan menurun.

\section{Simpulan Hasil Analisis}

\section{Simpulan uji korelasi}

Dengan diketahuinya koefisien korelasi (r) sebesar 0,244 tersebut berarti hipotesis (Ho) yang diajukan dalam penelitian ini dapat dipertanggungjawabkan, yaitu Tidak ada hubungan yang signifikan antara Biaya Promosi dengan Tingkat Penjualan pada Dealer Putra Rama Jaya Honda Kota Ponorogo.

Hal ini dapat dibuktikan dengan menggunakan $r_{\text {tabel }}=24-2=22$ adalah 0,404; sedangkan kriteria pengujiannya adalah jika $r_{\text {hitung }}>r_{\text {tabel }}$ maka Ha diterima dan Ho ditolak dan jika $r_{\text {hitung }}<r_{\text {tabel }}$ maka Ha ditolak dan Ho diterima. Berdasarkan kriteria pengujian tersebut jelaslah bahwa $r_{\text {hitung }}<$ $\mathrm{r}_{\text {tabel }}$ atau 0,244 $<0,404$ yang berarti $\mathrm{Ha}$ ditolak dan Ho diterima, yaitu tidak ada hubungan yang signifikan antara Biaya Promosi dan Tingkat Penjualan pada Dealer Putra Rama Jaya Honda Kota Ponorogo.

2. Simpulan uji fisher

Dengan diketahuinya uji fisher sebesar 1,394 tersebut berarti hipotesis (Ho) yang diajukan dalam penelitian ini dapat dipertanggungjawabkan, yaitu Tidak ada pengaruh yang signifikan antara Biaya Promosi dengan Tingkat Penjualan pada Dealer Putra Rama Jaya Honda Kota Ponorogo. Hal ini dapat dibuktikan dengan menggunakan $\mathrm{f}_{\text {tabel }}=24-2=22$ adalah 4,300; sedangkan kriteria pengujiannya adalah jika $f_{\text {hitung }}>f_{\text {tabel }}$ maka Ha diterima dan Ho ditolak dan jika $\mathrm{f}_{\text {hitung }}<\mathrm{f}_{\text {tabel }}$ maka Ha ditolak dan Ho diterima. Berdasarkan kriteria pengujian tersebut jelaslah bahwa $\mathrm{f}_{\text {hitung }}<\mathrm{f}_{\text {tabel }}$ atau 1,394 $<4,300$ yang berarti Ha ditolak dan Ho diterima, yaitu tidak ada pengaruh yang signifikan antara Biaya Promosi dan Tingkat Penjualan pada Dealer Putra Rama Jaya Honda Kota Ponorogo.

3. Simpulan Ujit

Dengan diketahuinya uji t sebesar 1,181 tersebut berarti hipotesis (Ho) yang diajukan dalam penelitian ini dapat dipertanggungjawabkan, yaitu Tidak ada pengaruh yang signifikan antara Biaya Promosi dengan Tingkat Penjualan pada Dealer Putra Rama Jaya Honda Kota Ponorogo. Hal ini dapat dibuktikan dengan menggunakan $\mathrm{t}_{\text {tabel }}=24-2=22$ adalah 1,717; sedangkan kriteria pengujiannya adalah jika $t_{\text {hitung }}>t_{\text {tabel }}$ maka Ha diterima dan Ho ditolak dan jika $\mathrm{t}_{\text {hitung }}<\mathrm{t}_{\text {tabel }}$ maka Ha ditolak dan Ho diterima. Berdasarkan kriteria pengujian tersebut jelaslah bahwa $\mathrm{t}_{\text {hitung }}<\mathrm{t}_{\text {tabel }}$ atau 1,223 $<1,717$ yang berarti Ha ditolak dan Ho diterima, yaitu tidak beda pengaruh yang signifikan antara Biaya Promosi dan Tingkat Penjualan pada Dealer Putra Rama Jaya Honda Kota Ponorogo. 


\section{PEMBAHASAN}

Hasil penelitian menunjukkan bahwa biaya promosi tidak berpengaruh terhadap tingkat penjualan.

Selanjutnya adalah pembahasan untuk uji regresi ( uji korelasi, uji fisher, dan uji t):

1. Pembahasan Uji Korelasi

Untuk uji korelasi diperoleh nilai $\mathrm{r}_{\text {hitung }}$ adalah 0,244 sedangkan $r_{\text {tabel }} 0,404$, hal ini berarti bahwa nilai $\mathrm{r}_{\text {hitung }}<\mathrm{r}_{\text {tabel }}(0,244<$ $0,404)$ dengan nilai signifikasi 0,000 dengan menggunakan batas signifikasi 0,05. Dengan demikian Ho diterima, artinya tidak ada hubungan biaya promosi terhadap tingkat penjualan pada dealer Putra Rama Jaya Honda.

2. Pembahasan Uji Fisher

Untuk uji korelasi diperoleh nilai $\mathrm{f}_{\text {hitung }}$ adalah 1,394 sedangkan $\mathrm{f}_{\text {tabel }} 4,300$, hal ini berarti bahwa nilai $\mathrm{f}_{\text {hitung }}<\mathrm{f}_{\text {tabel }}(1,394<$ 4,300) dengan nilai signifikasi 0,000 dengan menggunakan batas signifikasi 0,05 . Dengan demikian Ho diterima, artinya tidak ada pengaruh biaya promosi terhadap tingkat penjualan pada dealer Putra Rama Jaya Honda.

3. Pembahasan Ujit

Untuk uji korelasi diperoleh nilai $\mathrm{t}_{\text {hitung }}$ adalah 1,181 sedangkan $t_{\text {tabel }} 1,717$, hal ini berarti bahwa nilai $\mathrm{t}_{\text {hitung }}<\mathrm{t}_{\text {tabel }}(1,181<$ 1,717) dengan nilai signifikasi 0,000 dengan menggunakan batas signifikasi 0,05. Dengan demikian Ho diterima, artinya tidak ada pengaruh biaya promosi terhadap tingkat penjualan pada dealer Putra Rama Jaya Honda.

Hal ini pertegas Basu Swasta (2008: 406) "Kegiatan penjualan itu dipengaruhi beberapa faktor adalah kondisi dan kemampuan penjual, kondisi pasar, modal, kondisi organisasi perusahaan, dan faktor lain seperti periklanan, peragaan, kampanye, pemberian hadiah sering mempengaruhi penjualan".

Dari hasil penelitian wawancara menurut Anas Heri (Kepala Promosi) mengatakan bahwa "biaya promosi tidak mempunyai pengaruh terhadap tingkat penjualan. Untuk memperkenalkan produknya ke konsumen perusahaan tidak hanya melakukan promosi tetapi dapat dilakukan dengan cara lain misalnya pemberian hadiah, mengadakan lomba-lomba, panggung hiburan, panflet, koran dan sebar brosur agar konsumen lebih tertarik terhadap produk yang ditawarkan oleh perusahaan".

\section{PENUTUP}

\section{Simpulan}

Biaya promosi pada Dealer Putra Rama Jaya Honda dikatakan baik. Hal ini dapat dibuktikan nilai rata-rata sebanyak 13 bulan atau 54,17\% ini dapat dikatakan bahwa biaya promosi dari Dealer Putra Rama Jaya Honda baik.

Tingkat penjualan pada Dealer Putra Rama Jaya Honda dikatakan kurang baik. Hal tersebut dapat terlihat setiap bulan penjualannya mengalami naik turun, hal ini dapat dibuktikan nilai rata-rata sebanyak 11 bulan atau $46,83 \%$.

Biaya promosi tidak mempunyai Pengaruh Terhadap Tingkat Penjualan Pada Dealer Putra Rama Jaya Kota Ponorogo. Terbukti dari hasil analisis regresi yang memuat uji korelasi, uji f danuji t. Dari hasil uji korelasi diperoleh hasil nilai $r_{\text {hitung }}$ adalah 0,244 sedangkan $r_{\text {tabel }} 0,404$. Hal ini berarti bahwa nilai $r_{\text {hitung }}<r_{\text {tabel }}(0,244<0,404)$, artinya biaya promosi tidak mempunyai hubungan yang positif dengan tingkat penjualan pada Dealer Putra Rama Jaya Honda Kota Ponorogo.

Sedangkan dari hasil uji f diperoleh hasil nilai $\mathrm{f}_{\text {hitung }}$ adalah 1,394 sedangkan $\mathrm{f}_{\text {tabel }}$ adalah 4,300 hal ini berarti bahwa $\mathrm{f}_{\text {hitung }}<\mathrm{f}_{\text {tabel }}$ $(1,394<4,300)$, artinya biaya promosi tidak mempunyai pengaruh terhadap tingkat penjualan pada Dealer Putra Rama Jaya Honda Kota Ponorogo.

Selanjutnya dari hasil uji $\mathrm{t}$ diperoleh hasil nilai $\mathrm{t}_{\text {hitung }}$ adalah 1,181 sedangkan $\mathrm{t}_{\text {tabel }}$ 1,717 hal ini berarti bahwa nilai $\mathrm{t}_{\text {hitung }}<\mathrm{t}_{\text {tabel }}$ 
$(1,181<1,717)$ diperoleh hasil artinya biaya promosi tidak mempunyai pengaruh terhadap tingkat penjualan pada Dealer Putra Rama Jaya Honda Kota Ponorogo.

\section{Saran}

1. Bagi Dealer

Biaya promosi hendaknya benar-benar diperhatikan, karena walau bagaimana pun proses penjualan tidak akan berjalan tanpa adanya biaya promosi. Selain itu untuk memperkenalkan produknya ke konsumen perusahaan tidak hanya melakukan promosi tetapi dapat dilakukan dengan cara lain misalnya pemberian hadiah, mengadakan lomba-lomba, panggung hiburan, panflet, koran dan sebar brosur agar konsumen tidak beralih ke dealer lain.

2. Bagi Karyawan

Biaya promosi tidak memberikan hubungan serta pengaruh terhadap tingkat penjualan. Oleh karena itu karyawan hendaknya berkonsultasi kepada ketua apabila mengalami permasalahan dalam penjualan agar nantinya permasalahan tersebut dapat teratasi sehingga tingkat penjualan pada dealer pun tidak terganggu.

3. Bagi Peneliti Mendatang

Karena masih terdapatnya banyak faktor lain yang mempengaruhi tingkat penjualan selain variabel biaya promosi tersebut, maka diharapkan bagi peneliti selanjutnya untuk menambah variabel lain sehingga penelitiannya berkesinambungan serta saling melengkapi.

\section{DAFTAR PUSTAKA}

Andi Supangat. 2007. Statistika Dalam Kajian Deskriptif, Inferensi, dan Nonparametrik. Jakarta: Kencana Prenada Media Group.

Basu Swastha. 2007. Azas-azas Marketing. Yogyakarta: Liberty Offset.
Basu Swastha. 2008. Manajemen Pemasaran Modern. Yogyakarta: Universitas Gajah Mada.

Burhan Bungin. 2009. Metodologi Penelitian Kuantitatif. Jakarta: Kencana Prenada Media Group.

Freddy Rangkuti. 2009. Strategi Promosi yang Kreatif dan Analisis Kasus Integrated Marketing Communication. Jakarta: PT. Gramedia Pustaka Utama.

Gabriel Amin Silalahi. 2003. Metodologi Penelitian dan Studi Kasus. Sidoarjo: Citra Media.

Harmurti Subanar. 2001. Manajemen Usaha Kecil. Yogyakarta: Universitas Gajah Mada.

Husein Umar. 2000. Riset Pemasaran dan Perilaku Konsumen. Jakarta: PT Gramedia Pustaka Utama.

Juliansyah Noor. 2011. Metodologi Penelitian. Jakarta: Kencana Prenada Media Group.

Morissan. 2010. Periklanan Komunikasi Pemasaran Terpadu. Jakarta: Kencana.

Rambat Lupiyoadi. 2001. Manajemen Pemasaran Jasa. Jakarta: Salemba Empat.

Sofjan Assauri. 2010. Manajemen Pemasaran. Jakarta: Rajawali Pers.

Sugiyono. 2010. Penelitian Pendidikan Pendekatan Kuantitatif, Kualitatif dan $R \& D$. Bandung: Alfabeta.

Supranto. 2004. Analisis Multivariat: Arti dan Interpretasi. Jakarta: PT. Rineka Cipta.

Supranto. 2008. Statistik Teori dan Aplikasi. Jakarta: PT. Gelora Aksara Pratama.

Usman Rianse dan Abdi. 2012. Metodologi Penelitian Sosial dan Ekonomi Teori dan Aplikasi. Bandung: Alfabeta. 